\title{
HEPATITIS-C (HCV)-RELATED SOCIAL STIGMA; DEVELOPMENT OF A SCALE
}

\author{
AYESHA NOOR \\ Shaheed Zulfiqar Ali Bhutto Institute of Science and Technology, Islamabad, Pakistan
}

\begin{abstract}
In the past two decades, there has been a substantial research on disease related stigma especially the HIV stigma. However, only a few studies address the issue of $\mathrm{HCV}$ related social stigma. Through this study a scale was developed to measure HCV related social stigma. The scale was developed using literature review and interview with 26 individuals divided in five different groups. The nineteen item scale developed after this activity was distributed among 221 respondents. Results indicate that the scale shows robust psychometric properties with good alpha value having a four factor solution. The results are discussed with theoretical and practical implications that how this scale will facilitate measurement of $\mathrm{HCV}$ related social stigma in future studies.
\end{abstract}

\section{INTRODUCTION}

Globally, Hepatitis C (HCV) is ranked among the three most widespread chronic viral infections (McCarron, Main, \& Thomas, 1997; Soriano, Barreiro, \& Nunez, 2006; Alavian, Adibi, \& Zali, 2005) and HCV carriers are ten times higher than people carrying HIV(Global AIDS Epidemics, 2006), which makes HCV a major health problem worldwide (Brown Jr \& Gaglio, 2003). Apart from the medical complications associated with the disease like chronic liver cancer, it is also a source of psychological problems which include depression, anxiety (Alter \& Seeff, 2000; Golden et al., 2005) discrimination, social separation and stigma (Golden et al., 2006; Brener et al., 2007).

Stigma is an outcome of social process (Weiss et al., 2006) that disgraces individual within a social context (Goffman, 1963) and symbolizes degradation (Pearsall, 1999). Recent years witnessed increased attention of researchers towards HIV stigma (e.g. Fife \& Wright, 2000; Fontana \& Kronfol, 2004) and its social outcomes (Herek et al., 2002) including devaluation and discrimination by society (Bashir, 2011). Still, limited studies focus HCV related stigma (Paterson et al., 2007), though it is a noteworthy issue that requires attention (Hopwood \& Southgate, 2003; Zacks et al., 2006). There is also a dearth of knowledge on HCV stigma in those contexts (e.g. Pakistan), where it has emerged as a biggest threat. Butt (2008) suggested that being a complex social phenomenon, studies must address the socio cultural factors associated with $\mathrm{HCV}$ stigma. Occurrence of HCV is high in several Asian countries (Thanachartwet et al., 2007; Wang et al., 2008), and in majority of underdeveloped countries HCV stigma is not properly understood (Van Rie et al., 2008). If we specifically take the example of Pakistan, Kuo et al., (2006) suggests that very limited studies addressed the issue in this particular context, where prevalence of $\mathrm{HCV}$ is alarmingly high.

Another omission in $\mathrm{HCV}$ stigma literature is non availability of an instrument that can measure stigma in different social environment with robust psychometric properties across cultures (Van Brakel, 2003), as causes of stigma vary across cultures (Clair et al., 2005). To the best of our knowledge, no standardized instrument is available to measure social stigma associated with $\mathrm{HCV}$. The probable reason for omissions can be attributed to the fact that $\mathrm{HCV}$ is probably not a big threat to many developed countries, and in underdeveloped countries like Pakistan, where millions of people have lost their lives because of complications associated with $\mathrm{HCV}$; studies have paid limited attention towards HCV stigma and its measurement through a validated scale. Thus, an important contribution of the present study is its address to this gap under researched area.

\section{$\mathrm{HCV}$ related Social Stigma}

An individual can be socially stigmatized on the 
basis of some visible or non visible source (Tsui \& Gutek, 1999). The visible sources include age, color and race, while non visible sources are religion, occupation and illness (Williams \& O'Reilly, 1998). The invisibility of illness creates confusion resulting in social isolation of patients (Cox, 1993). The fear that the disease may transmit to others within a social group (Sandelowski, Lambe, \& Barroso, 2004) makes individuals socially worthless (Reidpath, Chan, Gifford, \& Allotey, 2005) causing deterioration in their physical and psychological well-being (Major \& O’Brien, 2005).

$\mathrm{HCV}$ carriers are considered socially irresponsible (Paterson et al., 2007) and they encounter stressful social interactions and isolation (Crocker \& Major, 1989). Studies also reveal that social stigma associated with disease also enhances medical complications (Riaz, Ahmad, \& Khanam, 2011), as fear of isolation and stigma forces the HCV carriers not to pursue the treatment properly (Madden \& Cavalieri, 2007). This fear can be a major reason for wide spread of disease as people avoid the tests of infectious diseases (Kalichman et al. 2005) due to fear of stigmatization (Hopwood, Treloar, \& Bryant, 2006). Awareness among masses about transmission of disease can reduce sufferings of patients (Butt, 2008), and they can have support from others regarding better treatment (Jones et al., 2012), which can help in reduction in spread of disease (Corrigan \& Penn, 1999).

\section{The study context: HCV in Pakistan}

A considerable geological difference has been noticed in prevalence of HCV globally (Sood et al., 2012). In South America, North America, Europe and Asia, there is considerable unpredictability in HBV and HCV occurrence (Pereira \& Levey, 1997; Sulowicz, Radziszewski \& Chowaniec, 2007). According to Aceijas and Rhodes (2007), HCV occurrence estimation by area varies as follows: $2-100 \%$ in Latin America, $8-90 \%$ in North America, 25-88\% in Australia and New Zealand, and 2-93\% in Western Europe, 10-96\% in Eastern Europe \& Central Asia, 10-100\% in South and South-East Asia, 34-93\% in East-Asia and Pacific, $5-60 \%$ in North Africa and Middle-East.

Prevalence of $\mathrm{HCV}$ in Pakistan is alarmingly high, and studies suggest that there are around 10 million HCV patients in Pakistan (Hamid et al., 2004). Similarly, studies on random samples (e.g. Idrees, Lal, Naseem, \& Khalid, 2008) confirm that the disease is spreading across country at a threatening rate. HCV has become a problem for every house hold. The mother of one colleague lost her life after struggling for two years against chronic liver cirrhosis caused by
$\mathrm{HCV}$, and so is the case with almost every family in Pakistan. Being a collectivist society (Hosftede, 1980), the disease has a number of social implications along with psychological problems (Qureshi, Khokhar, \& Shafqat, 2012). However, the social stigma associated with $\mathrm{HCV}$ in specific context of Pakistan has never been studied.

\section{RESEARCH METHODOLOGY}

\section{Scale Development}

The measurement of stigma has also remained an area of interest in the extant literature. Berger, Ferrans, and Lashley (2001)'s 40 item scale is considered to be the most reliable scale to measure stigma associated with HIV. Similarly, the scales to measure stigma associated with other diseases include perceived stigma for substance abuse (Link,1987), onchocerciasis (Brieger, Oshiname, \& Ososanya,1998), mental illness (Ritsher, Otilingam, \& Grajales 2003), leprosy (Tsutsumi et al., 2004) and epilepsy(Westbrook, Bauman, \& Shinnar, 1992; Austin, MacLeod, Dunn, Shen, \& Perkins, 2004; Austin \& Huberty 1993; Jacoby ,Baker, Smith, Dewey, \& Chadwick, 1993; Cramer et al., 1999; Tekle-Haimanot et al., 1992; Aziz, Akhtar, \& Hasan, 1997).

Van Brakel (2006) suggested that most of these instruments were developed focusing American context except few which focused the regional contexts. Kalichman et al. (2005) developed the multi item scale of HIV / AIDS stigma in South Africa. Moriya, Gir and Hayashida (1994) developed the stigma scale for Brazil, while Nyblade et al. (2005) developed it for Tanzania. However, limited studies attempted to develop a scale stigma associated with HCV (Habib \& Adorjany, 2003). These factors signify the need to develop a specific scale to measure social stigma associated with $\mathrm{HCV}$, which seems missing in literature.

For present study, HCV related social stigma was identified through literature review. As per Goffman (1963)'s findings, there are three aspects of stigma, and the items identified mainly relate to these three dimensions of social stigma. Later these items were extensively discussed by five focus groups comprising of twenty six individuals. These individuals included medical doctors treating the HCV carriers, and also with individuals who had an interaction with $\mathrm{HCV}$ patient. Based on this discussion, a total of 19 items were included in the scale which were adopted from various sources (e.g. Link, Cullen, Frank, \& Wozniak, 1987; Visser, Kershaw, Makin, \& Forsyth, 2008; Genberg et al., 2009; Kalichman et. al., 2005). The items responses were taken using a 5 point likert scale 
with 1 representing strongly disagree and 5 representing strongly agree.

\section{Sample}

The main criterion for recruitment of sample was that respondents must have some sort of social interaction with $\mathrm{HCV}$ patient either as a family member, friend a class fellow or coworker. For this purpose, four universities were visited, along with six banks, three public sector organizations and two hospitals in the cities of Rawalpindi and Islamabad. It was noticed with concern that almost all the people working in these organizations had some sort of social interaction with HCV patients. Most of them also told stories of their dear ones who lost their lives in battle against HCV. This explains the extent to which this disease has spread in Pakistan. However, the questionnaires were distributed only to those respondents who confirmed that they had a routine interaction with $\mathrm{HCV}$ patients.

The questionnaires were distributed with the help of HR department in these organizations. The objectives of this study were explained to respondents in detail. Some respondents were unable to comprehend the questionnaire due to low literacy level; hence questions were read aloud in front of them and responses were asked. The data was collected from December 2012 to April 2013. This required frequent visits to these organizations during this time period.

A total of 343 questionnaires were distributed in these organizations, and 233 were received, of which 11 were incomplete; hence, 221 were used for final analysis making response rate as $64 \%$ which seemed adequate. The composition of this sample included 59\% male and $41 \%$ female respondents. As for educational qualification, $30 \%$ of respondents had less than school certificate level education, $22 \%$ had bachelor degree, while $48 \%$ held masters degree. The age composition of respondents indicated that $40 \%$ respondents were between the age of 20 to 30 years; $26 \%$ between 31 to 40 years; $22 \%$ between 41 to 50 years and $22 \%$ were above 50 years of age.

\section{RESULTS}

For pilot testing initially, the questionnaires were distributed among 63 respondents and a satisfactory alpha reliability value of 0.886 was observed. Data was collected from 221 respondents. The values of corrected items, total correlation and cronbach alpha are shown in Table I, while Table II indicates the items mean and standard deviation values.
TABLE 1

HCV related stigma scale corrected item - total correlation and cronbach alpha coefficients if items deleted item $(n=221)$

\begin{tabular}{lll}
\hline Items\# & $\mathbf{r}_{\text {i-t }}$ & $\mathbf{a 1}$ \\
\hline 1 & .539 & .881 \\
2 & .619 & .880 \\
3 & .647 & .877 \\
4 & .863 & .870 \\
5 & .833 & .871 \\
6 & .670 & .879 \\
7 & .301 & .903 \\
8 & .581 & .879 \\
9 & .384 & .905 \\
10 & .361 & .894 \\
11 & .386 & .889 \\
12 & .539 & .881 \\
13 & .619 & .880 \\
14 & .647 & .877 \\
15 & .863 & .870 \\
16 & .833 & .871 \\
17 & .696 & .876 \\
18 & .714 & .873 \\
19 & .842 & .873 \\
\hline
\end{tabular}

The results of factor analysis with varimax orthogonal rotation are shown in Table 2. A total of 19 items were analyzed showing the four factor solution.

\section{DISCUSSION}

The basic objective of the present study was to firstly introduce the concept of HCV related social stigma, and then to develop a robust instrument to measure it. There are important insights which this study has added to the extant literature on $\mathrm{HCV}$ related social stigma. Since HCV carriers are stigmatized by 'others' around them, it is important to analyze the feelings and perceptions of these individuals to correctly address the issue. Parker and Aggelton (2003), while discussing HIV stigma concluded, that stigma is an important issue and the uninfected individuals have to live and accommodate people with HIV. On the same analogy, this study suggests that through awareness and tolerance to live with $\mathrm{HCV}$ carriers and not to discernment them socially, the psychological miseries of HCV carriers can be reduced to some extent, if not totally eradicated.

The scale developed to analyze the social stigma associated with $\mathrm{HCV}$ is found to have robust reliability. The four dimensions identified as a result of factor analysis are in line with stigma theory presented through his seminal work by (Goffman, 1963), which is social isolation, negative social perception, fear of contagion and pity attitude. These dimensions indicate the types of social stigma the $\mathrm{HCV}$ carriers face on day-to-day basis. 
TABLE 2

HCV related stigma scale five factors, factor loadings and items

\begin{tabular}{|c|c|c|c|c|}
\hline Factor & & Loading & Item & \\
\hline \multirow[t]{10}{*}{ 1.Social Isolation } & $\begin{array}{l}9 \text { items, } \alpha=0.821 \text {, Eigen } \\
\text { value }=7.33,32.22 \%\end{array}$ & 0.863 & 1 & HCV carriers should not be trusted \\
\hline & & 0.876 & 2 & $\begin{array}{l}\text { Although } \mathrm{HCV} \text { patients may seem all right it is } \\
\text { dangerous to forget for a moment that they are } \\
\mathrm{HCV} \text { carriers. }\end{array}$ \\
\hline & & 0.878 & 3 & $\begin{array}{l}\text { I would not like to sit next to someone with } \mathrm{HCV} \\
\text { in public transport. }\end{array}$ \\
\hline & & 0.594 & 6 & $\begin{array}{l}\text { I would not like to have friendship with someone } \\
\text { having HCV. }\end{array}$ \\
\hline & & 0.831 & 7 & $\begin{array}{l}\text { It is safe for a person with HCV to look after } \\
\text { somebody else's children. }\end{array}$ \\
\hline & & 0.876 & 12 & $\begin{array}{l}\text { People living with } \mathrm{HCV} \text { in this community face } \\
\text { rejection from their peers. }\end{array}$ \\
\hline & & 0.878 & 13 & $\begin{array}{l}\text { People living with } \mathrm{HCV} \text { in this community face } \\
\text { neglect from their family members. }\end{array}$ \\
\hline & & 0.893 & 15 & $\begin{array}{l}\text { People with HCV should be allowed to fully } \\
\text { participate in social events in this community } \\
\text { (R). }\end{array}$ \\
\hline & & 0.842 & 16 & $\begin{array}{l}\text { I feel comfortable being seen in public with } \mathrm{HCV} \\
\text { carrier }(\mathrm{R})\end{array}$ \\
\hline & & 0.841 & 9 & I would not employ someone with HCV. \\
\hline \multirow[t]{3}{*}{$\begin{array}{l}\text { 2. Negative social } \\
\text { Perception }\end{array}$} & $\begin{array}{l}3 \text { items, } \alpha=0.713 \text {, Eigen } \\
\text { value }=2.13,7.33 \%\end{array}$ & 0.851 & 5 & $\begin{array}{l}\text { I think less of someone because they have } \\
\text { HCV. }\end{array}$ \\
\hline & & 0.851 & 11 & I feel uncomfortable around people with $\mathrm{HCV}$. \\
\hline & & 0.833 & 19 & $\begin{array}{l}\text { A person with HCV must have done something } \\
\text { wrong and deserves to be punished. }\end{array}$ \\
\hline \multirow[t]{3}{*}{$\begin{array}{l}\text { 3: Fear of } \\
\text { Contagion }\end{array}$} & $\begin{array}{l}3 \text { items, } \alpha=0.761 \text {, Eigen } \\
\text { value }=1.13,3.22 \%\end{array}$ & 0.939 & 8 & I feel afraid to be around people with HCV. \\
\hline & & 0.604 & 14 & $\begin{array}{l}\text { Most people would not buy edibles from a } \\
\text { shopkeeper or food seller that they knew had } \\
\text { HCV. }\end{array}$ \\
\hline & & 0.939 & 17 & $\begin{array}{l}\text { I am afraid of catching the } \mathrm{HCV} \text { from an affected } \\
\text { person. }\end{array}$ \\
\hline \multirow[t]{3}{*}{ 4: Pity attitude } & $\begin{array}{l}3 \text { items, } \alpha=0.87 \text {, Eigen } \\
\text { value }=2.12,5.42 \%\end{array}$ & 0.632 & 4 & Having HCV is just a matter of bad luck. \\
\hline & & 0.844 & 10 & $\begin{array}{l}\text { People with HCV deserve as much respect as } \\
\text { anyone else. }\end{array}$ \\
\hline & & 0.809 & 18 & I feel sorry for a person with HCV. \\
\hline
\end{tabular}

Almost each and every Pakistani observes people dying of HCV in their surroundings. Thus, fear associated with this disease is alarmingly high, which itself is a major source of social stigma. People avoid HCV carriers with the unknown fear that they might catch the disease. Lack of awareness plays an important role in this regard as most of the people don't know the exact cause of disease, and this ambiguity results in negative perception about the disease. In an Asian context, the problem becomes more serious regarding HIV. Bhattacharya (2004) suggested that Aids is considered a dirty disease in South Asia; we observed similar opinion among masses about HCV. People tend to isolate HCV carriers socially, and do not prefer social interaction with them. Earlier studies suggest that lack of awareness and illiteracy further intensify the issue manifold. During 
interviews, majority of respondents indicated that they do not prefer to eat with HCV carriers or to interact with them. They considered that HCV spreads using same utensils or normal social interaction like hand shacking and hugging. Some families indicated that they have separated the utensils etc, of patients, although $\mathrm{HCV}$ does not spread through this mode.

People generally think it is because of sins or intentional wrong doing by the HCV carrier, and thus he/ she deserved this punishment in the form of this disease. Hence, a person who deserves sympathy is subjected to negative perception in social context, making his/her life more miserable. Some people take it as anyone having this disease is not a normal person, and thus they deserve sympathy or which we call petty attitude. This attitude also causes a sort of discrimination with the HCV carriers. People try to show sympathy to them which may hurt their ego. In social gatherings or normal day-to-day life, the HCV carriers are discussed as being unfortunate ones, who deserve special sympathy and consideration; thus, indirectly, the petty attitude can be considered a source of social stigma.

Another important issue which the HCV carriers may face is stigma at workplace. Studies indicate that HIV is a source of workplace stigma in various contexts including Pakistan (Bashir, 2011). Similarly, HCV carriers are less likely to be offered jobs, or at jobs they are less likely to have equal opportunities parallel to a normal employee. So, the social stigma associated with $\mathrm{HCV}$ can be seen at homes, at shopping malls, at social gatherings and at workplace.

This study made an important contribution to literature and theory of stigma by developing a scale to measure social stigma associated with HCV. There are not many scales available to comprehensively measure $\mathrm{HCV}$ related social stigma with good psychometric properties. It is evident from the initial testing that this scale will help the researchers to correctly assess and measure the stigma. On practical side, studies using this scale will help to identify the miseries being faced by HCV patients, and to prose the remedial measures so that the HCV carriers can lead a normal life like other people. It will help to raise awareness among masses that $\mathrm{HCV}$ carriers are normal human beings; the disease is cure able and does not spread with normal social interaction.

In the end, we must acknowledge the limitations of the study. Since the major objective was to develop a test, the test-retest reliability was not explored; this aspect must be addressed by future researchers. Another limitation was sample, $\mathrm{HCV}$ is a disease spread across Pakistan, but due to limited resources available, the data could not be collected from many areas of Pakistan. The future studies should try to use a more comprehensive sample to conform psychometric properties of this scale.

\section{ANNEXURE HCV Social Stigma Scale}

1 HCV carriers should not be trusted

2 Although $\mathrm{HCV}$ patients may seem all right it is dangerous to forget for a moment that they are $\mathrm{HCV}$ carriers.

3 I would not like to sit next to someone with $\mathrm{HCV}$ in public transport.

4 Having HCV is just a matter of bad luck.

5 I think less of someone because they have HCV.

6 I would not like to have friendship with someone having HCV.

7 It is safe for a person with $\mathrm{HCV}$ to look after somebody else's children(R).

8 I feel afraid to be around people with HCV.

9 I would not employ someone with HCV.

10 People with $\mathrm{HCV}$ deserve as much respect as anyone else.

11 I feel uncomfortable around people with HCV.

12 People living with $\mathrm{HCV}$ in this community face rejection from their peers.

13 People living with $\mathrm{HCV}$ in this community face neglect from their family members.

14 Most people would not buy edibles from a shopkeeper or food seller that they knew had HCV.

15 People with HCV should be allowed to fully participate in social events in this community (R).

16 I feel comfortable being seen in public with $\mathrm{HCV}$ carrier (R).

17 I am afraid of catching the HCV from an affected person.

18 I feel sorry for a person with HCV.

19 A person with $\mathrm{HCV}$ must have done something wrong and deserves to be punished.

\section{REFERENCES}

Aceijas, C., \& Rhodes, T. (2007). Global estimates of prevalence of $\mathrm{HCV}$ infection among injecting drug users. International Journal of Drug Policy, 18, 352-358.

Alavian, S.M., Adibi, P., \& Zali, M.R. (2005). Hepatitis $\mathrm{C}$ virus in Iran: Epidemiology of an emerging infection. Arch Iranian Me,8,84-90.

Alter, H.J.,\& Seeff, L.B. (2000). Recovery, persistence, and sequelae in hepatitis $\mathrm{C}$ virus infection: a perspective on long-term outcome. Seminar in Liver Diseases, 20,17-35.

Austin, J. K., \& Huberty, T. J. (1993). Development of the child attitude toward illness scale. Journal of Pediatric Psychology, 18(4), 467-480.

Austin, J. K., MacLeod, J., Dunn, D. W., Shen, J., \& Perkins, S. M. (2004). Measuring stigma in 
children with epilepsy and their parents: instrument development and testing. Epilepsy \& Behavior, 5(4), 472-482.

Aziz, H., Akhtar, S. W., \& Hasan, K. Z. (1997). Epilepsy in Pakistan: Stigma and Psychosocial Problems. A Population-Based Epidemiologic Study. Epilepsia, 38(10), 1069-1073.

Bashir, S. (2011). HIV/AIDS stigma at the workplace: Exploratory findings from Pakistan. SAHARA J (Journal of Social Aspects of HIV/AIDS Research Alliance), 8(3), 156-161.

Berger, B. E., Ferrans, C. E., \& Lashley, F. R. (2001). Measuring stigma in people with HIV: Psychometric assessment of the HIV stigma scale. Research in nursing \& health, 24(6), 518-529.

Bhattacharya, G. (2004). Health care seeking for HIV/ AIDS among South Asians in the United States. Health \& Social Work, 29(2), 106-115.

Brener, L., Hippel, W. V., \& Kippax, S. (2007). Prejudice among health care workers toward injecting drug users with hepatitis C: Does greater contact lead to less prejudice?. International Journal of Drug Policy, 18, 381-387.

Brieger, W. R., Oshiname, F. O., \& Ososanya, O. O. (1998). Stigma associated with onchocercal skin disease among those affected near the Ofiki and Oyan Rivers in western Nigeria. Social Science \& Medicine, 47(7), 841-852.

Brown Jr, R. S., \& Gaglio, P. J.(2003). Scope of worldwide hepatitis C problem. Liver Transplantation, 9(11), S10-S13.

Butt,G. (2008). Stigma in the context of hepatitis C: concept analysis. Journal of Advanced Nursing, 62(6), 712-724.

Clair, J. A., Beatty, J., \& Maclean,T. L. (2005). Out of sight but not out of mind:Managing invisible social identities in the workplace. Academy of Management Review, 30(1), 78-95.

Corrigan, P. W., \& Penn, D. L.(1999). Lessons From Social Psychology on Discrediting Psychiatric Stigma. American Psychologist, 54(9), 765-776.

Cox, T. (1993). Cultural diversity in organizations. San Francisco:Berrett-Koehler.

Crocker, J., \& Major, B. (1989). Social stigma and selfesteem: The self-protective properties of stigma. Psychological Review, 96, 608-630.

Cramer, J. A., Westbrook, L. E., Devinsky, O., Perrine, K., Glassman, M. B., \& Camfield, C. (1999). Development of the Quality of Life in Epilepsy Inventory for Adolescents: The QOLIE-AD-48. Epilepsia, 40(8), 1114-1121.

Fife, B. L., \& Wright, E. R. (2000). The dimensionality of stigma: A comparison of its impact on the self of persons with HIV/AIDS and cancer. Journal of
Health and Social Behavior, 41(1), 50-67.

Fontana, R. J., \& Kronfol, Z. (2004). The patient's perspective in hepatitis C. Hepatology, 39(4), 903905.

Genberg, B. L., Hlavka, Z., Konda, K. A., Maman, S., Chariyalertsak, S., Chingono, A.,

Mbwambo, J., Modiba, P., Rooyen, H. V., Celentano, D. D.(2009). A comparison of HIV/AIDS-related stigma in four countries: Negative attitudes and perceived acts of discrimination towards people living with HIV/AIDS. Social Science \& Medicine ,68(12), 2279-2287.

Goffman, E. (1963). Stigma: Notes on the Management of Spoiled Identity.

Golden, J., O'Dwyer, A. M., \& Conroy, R. M. (2005). Depression and anxiety in patients with hepatitis $\mathrm{C}$ : prevalence, detection rates and risk factors. General Hospital Psychiatry, 27(6), 431-438.

Golden, J., Conroy, R. M., O’Dwyer, A.M., Golden, D., \& Hardouin, J. B. (2006). Illness-related stigma, mood and adjustment to illness in persons with hepatitis C. Social Science \& Medicine, 63(12), 3188-3198.

Habib, S. E., \& Adorjany, L. V. (2003). Hepatitis C and injecting drug use: The realities of stigmatisation and discrimination. Health Education Journal, 62(3), 256-265.

Hamid, S., Umar, M., Alam, A., Siddiqui, A., Qureshi, H., \& Butt, J. (2004). PSG consensus statement on management of hepatitis $\mathrm{C}$ virus infection-2003. Journal-Pakistan Medical Association, 54(3), 146149.

Herek, G. M., Capitanio, J. P., \& Widaman, K. F. (2002). HIV-related stigma and knowledge in the United States: prevalence and trends, 1991-1999. American Journal of Public Health, 92(3), 371-377.

Hofstede, G.(1980). Culture's Consequences: International Differences in Work Related Values, SAGE, London.

Hopwood, M., \& Southgate, E. (2003). Living with hepatitis C: A sociological review. Critical Public Health, 13(3), 251-267.

Hopwood, M., Treloar, C., \& Bryant, J. (2006). Hepatitis $\mathrm{C}$ and injecting-related discrimination in New South Wales, Australia. Drugs: Education, Prevention, and Policy, 13(1), 61-75.

Idrees, M., Lal, A., Naseem, M., \& Khalid, M. (2008). High prevalence of hepatitis $\mathrm{C}$ virus infection in the largest province of Pakistan. Journal of Digestive Diseases, 9(2), 95-103.

Jacoby, A., Baker, G., Smith, D., Dewey, M., \& Chadwick, D. (1993). Measuring the impact of epilepsy: the development of a novel scale. Epilepsy Research, 16(1), 83-88. 
Jones,L., Atkinson,A., Porcellato,L., Bates, G. , McCoy, E., Beynon,C., McVeigh,J., \& Bellis,M. (2012). A systematic review of qualitative research on the views, perspectives and experiences of hepatitis $\mathrm{B}$ and $\mathrm{C}$ testing among practitioners and people at greatest risk of infection. . Liverpool: Centre for Public Health.

Kalichman, S. C., Simbayi, L. C., Jooste, S., Toefy, Y., Cain, D., Cherry, C., \& Kagee, A. (2005). Development of a brief scale to measure AIDSrelated stigma in South Africa. AIDS and Behavior, 9(2), 135-143.

Kuo, I. , Hasan, S., Galai,N., Thomas,D.L, Zafar,T. Ahmed,M.A.,\& Steffanie Strathdee,S.A (2006). High HCV seroprevalence and HIV drug use risk behaviors among injection drug users in Pakistan. Harm Reduction ,3,26.

Link, B. G. (1987). Understanding labeling effects in the area of mental disorders: An assessment of the effects of expectations of rejection. American Sociological Review, 96-112.

Link, B. G., Cullen, F. T., Frank, J., \& Wozniak, J. F. (1987). The social rejection of former mental patients: understanding why labels matter. American Journal of Sociology, 1461-1500.

Madden, A., \& Cavalieri, W. (2007). Hepatitis C prevention and true harm reduction. International Journal of Drug Policy, 18(5), 335-337.

Major, B., \& O'Brien, L. T. (2005). The social psychology of stigma. Annual Review. Psychology, 56, 393421.

McCarron, B., Main, J., \& Thomas, H. C. (1997). HIV and hepatotropic viruses: interactions and treatments. International Journal of STD \& AIDS, 8(12), 739-746.

Moriya TM, Gir E \& Hayashida M (1994) A scale of attitudes towards AIDS: a psychometric analysis. Revista Latino-Americana De Enfermagem, 2(2), 37-53.

Nyblade, L., MacQuarrie, K., Phillip, F., Kwesigabo, G., Mbwambo, J., \& Ndega, J. (2005). Working report measuring HIV stigma: Results of a field test in Tanzania. Washington, DC: Report for United States Agency for International Development.

Parker, R., \& Aggleton, P. (2003). HIV and AIDS-related stigma and discrimination: a conceptual framework and implications for action. Social Science \& Medicine, 57(1), 13-24.

Paterson, B. L., Backmund, M., Hirsch, G., \& Yim, C. (2007). The depiction of stigmatization in research about hepatitis C. International Journal of Drug Policy, 18(5), 364-373.

Pearsall, D. A. (Ed.). (1999). Chaucer to spenser: a critical reader (p. 187). Blackwell.
Pereira, B. J., \& Levey, A. S. (1997). Hepatitis C virus infection in dialysis and renal transplantation. Kidney International, 51(4), 981.

Qureshi, M. O., Khokhar, N., \& Shafqat, F. (2012). Severity of Depression in Hepatitis B and Hepatitis C Patients. Journal of the College of Physicians and Surgeons-Pakistan: JCPSP, 22(10), 632-634.

Reidpath, D. D., Chan, K. Y., Gifford, S. M., \& Allotey, P. (2005). 'He hath the French pox': stigma, social value and social exclusion. Sociology of Health \& Illness, 27(4), 468-489.

Riaz, Z., Ahmad, R., \& Khanam, S. J.(2011). Does Social Support and Self Esteem Determine Depression in Chronically Ill Patients?.

Ritsher, J. B., Otilingam, P. G., \& Grajales, M. (2003). Internalized stigma of mental illness: psychometric properties of a new measure. Psychiatry Research, 121(1), 31-49.

Report on the Global AIDS Epidemic. (2006). Available from:http://www.unaids.org/en/HIV data/2006GlobalReport/ default. asp Accessed on 10.6.2007.

Sandelowski, M., Lambe, C., \& Barroso, J. (2004). Stigma in HIV-positive women. Journal of Nursing Scholarship, 36(2), 122-128.

Sulowicz,W., Radziszewski, A., Chowaniec, E . (2007). Hepatitis $\mathrm{C}$ virus infection in dialysis patients. Hemodialysis International, 11(3), 286-295.

Soriano, V., Barreiro, P., \& Nuñez, M. (2006). Management of chronic hepatitis $\mathrm{B}$ and $\mathrm{C}$ in HIV-coinfected patients. Journal of Antimicrobial Chemotherapy, 57(5), 815-818.

Sood, A., Sarin, S. K., Midha, V., Hissar, S., Sood, N., Bansal, P., \& Bansal, M. (2012). Prevalence of hepatitis $\mathrm{C}$ virus in a selected geographical area of northern India: a population based survey. Indian Journal of Gastroenterology, 31(5), 232-236.

Tekle-Haimanot, R., Forsgren, L., Gebre-Mariam, A., Abebe, M., Holmgren, G., Heijbel, J., \& Ekstedt, J. (1992). Attitudes of rural people in central Ethiopia towards leprosy and a brief comparison with observations on epilepsy. Leprosy Review, 63(2), 157.

Thanachartwet, V., Phumratanaprapin, W., Desakorn, V., Sahassananda, D., Wattanagoon, Y., Chaiprasert, A., ... \& Supaporn, T. (2007). Viral hepatitis infections among dialysis patients: Thailand registry report. Nephrology, 12(4), 399-405.

Tsui, A. S., \& Gutek, B. A. (1999). Demographic differences in organizations: Current research and future directions. Lexington Books.

Tsutsumi, A., Izutsu, T., Islam, M. A., Amed, J. U., Nakahara, S., Takagi, F., \& Wakai, S. (2004). Depressive status of leprosy patients in Bangladesh: 
association with self-perception of stigma. Leprosy Review, 75(1), 57-66.

Van Brakel, W. H. (2003). Measuring leprosy stigma-a preliminary review of the leprosy literature. International Journal of Leprosy and Other Mycobacterial Diseases, 71(3), 190-197.

Van Brakel, W. H. (2006). Measuring health-related stigma - a literature review. Psychology, Health \& Medicine, 11(3), 307-334.

Van Rie, A., Sengupta, S., Pungrassami, P., Balthip, Q., Choonuan, S., Kasetjaroen, Y., ... \& Chongsuvivatwong, V. (2008). Measuring stigma associated with tuberculosis and HIV/AIDS in southern Thailand: exploratory and confirmatory factor analyses of two new scales. Tropical Medicine \& International Health, 13(1), 21-30.

Visser, M. J., Kershaw, T., Makin, J. D., \& Forsyth, B. W. (2008). Development of parallel scales to measure HIV-related stigma. AIDS and Behavior, 12(5), 759-771.
Wang, S. M., Liu, J. H., Chou, C. Y., Huang, C. C., Shih, C. M., \& Chen, W. (2008). Mortality in hepatitis C-positive patients treated with peritoneal dialysis. Peritoneal Dialysis International, 28(2), 183-187.

Weiss, M. G., Ramakrishna, J., \& Somma, D. (2006). Health-related stigma: Rethinking concepts and interventions 1. Psychology, Health \& Medicine, 11(3), 277-287.

Westbrook, L. E., Bauman, L. J., \& Shinnar, S. (1992). Applying stigma theory to epilepsy: a test of a conceptual model. Journal of Pediatric Psychology, 17(5), 633-649.

Williams, K. Y., \& O'Reilly, C. A. (1998). Demography and diversity in organizations: A review of 40 years of research. Research In Organizational Behavior, 20, 77-140.

Zacks, S., Beavers, K., Theodore, D., Dougherty, K., Batey, B., Shumaker, J., ... \& Fried, M. W. (2006). Social stigmatization and hepatitis $\mathrm{C}$ virus infection. Journal of Clinical Gastroenterology, 40(3), 220-224. 